SVU- International Journal of Veterinary Sciences, 2 (2): 91-100, 2019.

Print ISSN: 2535-1826

\title{
Experimental Co-infection of Low Pathogenic Avian Influenza Virus (H9N2) and Escherichia Coli in SPF Broiler Chickens
}

\section{Mohamed E. Taha*1, Ahmed I. A. Ibrahim², Nabila Osman², Mohamed S. Ahmed ${ }^{2}$, Ahmed F. Gaber $^{3}$, Soad A. Nasef ${ }^{3}$}

${ }^{1}$ Reference Laboratory for Veterinary Quality Control on Poultry production (RLQP), Animal Health Research Institute, Agriculture Research Center, Luxor branch, Egypt, ${ }^{2}$ Department of Poultry and Rabbit Diseases, Faculty of Veterinary Medicine, South Valley University, Qena, Egypt, ${ }^{3}$ Referenc Laboratory for Veterinary Quality Control on Poultry Production (RLQP), Animal Health Research Institute, Agriculture Research Center, Dokki, Giza, Egypt.

\section{Abstract}

The work was implemented to evaluate the pathogenicity of H9N2 when co-infected with the E.coli. Avian influenza H9N2 virus strain A/chicken/Egypt/1618F/2016 which was isolated from Luxor province during 2016 and E.coli serotype $\mathrm{O}_{78}$ were used in this research. Sixty SPF birds were divided into 6 groups of ten birds each. At age 21 days, group 1 was inoculated with H9N2 only, group 2 received E.coli and three days later received H9N2, group 3 inoculated with H9N2 and after three days received E.coli, group 4 was challenged with E.coli and H9N2 at the same time, group 5 was inoculated with E.coli only, and group 6 was designed as a negative group. Clinical signs, postmortem examination, and serological examination were monitored for 15 days. The H9N2 virus presence was assessed in tracheal and cloacal swabs using real-time PCR. The most severe signs and lesions were observed in groups (3, and 4), with also high mortality rate than other groups with a percentage of $20 \%$. Groups 3 , and 4 showed a longer duration in virus shedding in the tracheal and cloacal samples. The hemagglutination inhibition test, group 4 showed high HI antibody titer against AIV-H9N2 antigen than other groups, while group 2 showed the lowest HI antibody titer against AIV-H9N2 antigen than other groups that received only the H9N2 virus. In conclusion, the outcomes of this study revealed that the infection of H9N2 with E.coli can exacerbate the clinical outcomes and mortality rates which leads to higher economic losses in chicken flocks.

Keywords: Co-infection, E.coli, LPAI (H9N2), Pathogenicity, SPF.

\section{DOI:}

Received: June 10, 2019

Accepted: July 15, 2019

Published: July 27, 2019

*Corresponding Author: Mohamed Elsayed Taha

E-mail: drmido_2004@yahoo.com

Citation: Taha et al., Experimental Co-infection of Low Pathogenic Avian Influenza Virus (H9N2) and Escherichia Coli in SPF Broiler Chickens. SVU-IJVS 2019, 2 (2): 91-100.

Copyright: (C) Taha et al. This is an open access article distributed under the terms of the creative common attribution license, which permits unrestricted use, distribution and reproduction in any medium provided the original author and source are created.

Competing interest: The authors have declared that no competing interest exists. 
Avian influenza virus is an important poultry disease causing great epidemics resulting in higher economic losses. Avian Influenza virus related to the type of (A), Orthomyxoviridae family and possess 18 hemagglutinins and also have 11 subneuraminidases (Tong et al., 2013). LPAIV has distributed in a large scale in domestic poultry around the world (Karimi et al., 2010). One possible illustration for this high mortality rates and significant economic losses can be mixed with causes of infection of other respiratory diseases (Seifi et al., 2010). In Egypt, the first introduction of H9N2 LPAIV was reported in May 2011 in commercial clinically healthy bobwhite quail farm (El-Zoghby et al., 2012), then the virus was detected in commercial chicken broilers, breeders and layer flocks (Ahmed et al., 2013).

Infections with H9N2 viruses in domestic poultry are commonly correlated with the reduced feed intake and consuming water and drop in egg production, and moderate respiratory symptoms with low mortality rate (Swayne and Halvorson, 2008). But over the past ten years, the epidemic spread of H9N2 infections with severe clinical symptoms, excessive numbers of mortalities (20-65 $\%$ ) and loss in production reached to $75 \%$ which have been mentioned in commercial poultry flocks (Suarez, 2008).

The co-infection of the H9N2 virus with other pathogens which cause mainly respiratory disease can complicate respiratory disease syndromes and cause acute disease condition and high numbers in mortalities (Pan et al., 2012; Hassan et al., 2017; Ismail et al., 2018; Mahana et al., 2019).

Colibacillosis is the most significant infectious disease in poultry. The responsible causative factor of the
Colibacillosis is E.coli that belonged to Enterobacteriaceae family, it is a gramnegative in stain and rod in shape, and it is an anaerobic and non-pathogenic bacteria which lives commensally in the digestive system. Avian Pathogenic E.coli may infect chickens and cause variable disease forms of E.coli e.g. yolk sac infection, coligranuloma and colisepticaemia. The most common respiratory origin of E.coli is colisepticaemia, (Saif et al., 2008; Persoons et al., 2011). Risk factors that affect the infection of colisepticaemia respiratory origin and primary respiratory infections caused by Mycoplasma species or viral infections of both wildtype and vaccinal strains of unfavorable housing conditions such as high concentrations of air ammonia overcrowding and a high infective dose (Lutful Kabir, 2010).

This study was carried out to determine the effect of the co-infections of the $\mathrm{H} 9 \mathrm{~N} 2$ virus and E.coli $\mathrm{O}_{78}$ in SPF chickens, also understand the impact of the E.coli on the H9N2 pathogenesis (clinical pictures, and lesions), virus shedding during single H9N2 infection or E.coli coinfection).

\section{Materials and Methods}

\section{Determination of the EID50 of H9N2:}

The virus strain used in this study was A/chicken/1618F/2016 with (Gene bank Acc. No., MH734794). H9N2 field strain was isolated and characterized in Reference Laboratory for Veterinary Quality Control on Poultry production (RLQP), Animal Health Research Institute, Agriculture Research Center. This virus was propagated in embryonated 10 days old chicken eggs and the 50\% Egg Infectious Disease $\left(\right.$ EID $\left._{50}\right)$ was determined as recommended by (Reed and Muench,1938). The virus strain was 
examined for confirmation that its freedom from other respiratory viral diseases.

\section{E. coli $O_{78}$ strain:}

E.coli serotype $\mathrm{O}_{78}$ was used in rate of 1 $\mathrm{ml}$ of saline containing $10^{8}$ colony forming unit (CFU) E. coli/ $\mathrm{ml}$, and originally isolated from chicken, the inoculum was prepared according to (Fernandez et al., 2002).

\section{Experimental design:}

Sixty 21-day-old SPF birds were randomly divided into 6 groups with 10 birds in each group. All of the birds were put in negative pressure isolators. Group 1 was administrated $10^{7}$ EID $50 / \mathrm{ml}$ (Mahana et al.,2019) of H9N2/chicken. Group 2 infected with E.coli $\mathrm{O}_{78}\left(10^{8} \mathrm{CFU} / \mathrm{ml}\right)$ /chicken and, three days later, was received $10^{7} \mathrm{EID}_{50}$ of H9N2/ chicken. Group 3 was inoculated with $10^{7} \mathrm{EID}_{50}$ of H9N2/ chicken and, three days later, was received of E.coli $\mathrm{O}_{78} \quad\left(10^{8} \mathrm{CFU} / \mathrm{ml}\right) /$ chicken. Group 4 was inoculated with E.coli $\mathrm{O}_{78}$ $\left(10^{8} \mathrm{CFU} / \mathrm{ml}\right) /$ chicken, and at the same once, $10^{7}$ EID $_{50}$ of H9N2/chicken. Group 5, birds were infected with E.coli $\mathrm{O}_{78}\left(10^{8}\right.$ $\mathrm{CFU} / \mathrm{ml}$ ) /chicken, and Group 6 was taken an intraperitoneal injection of the sterile physiological saline as a control, as shown in Table (1).

Table (1): Experimental design

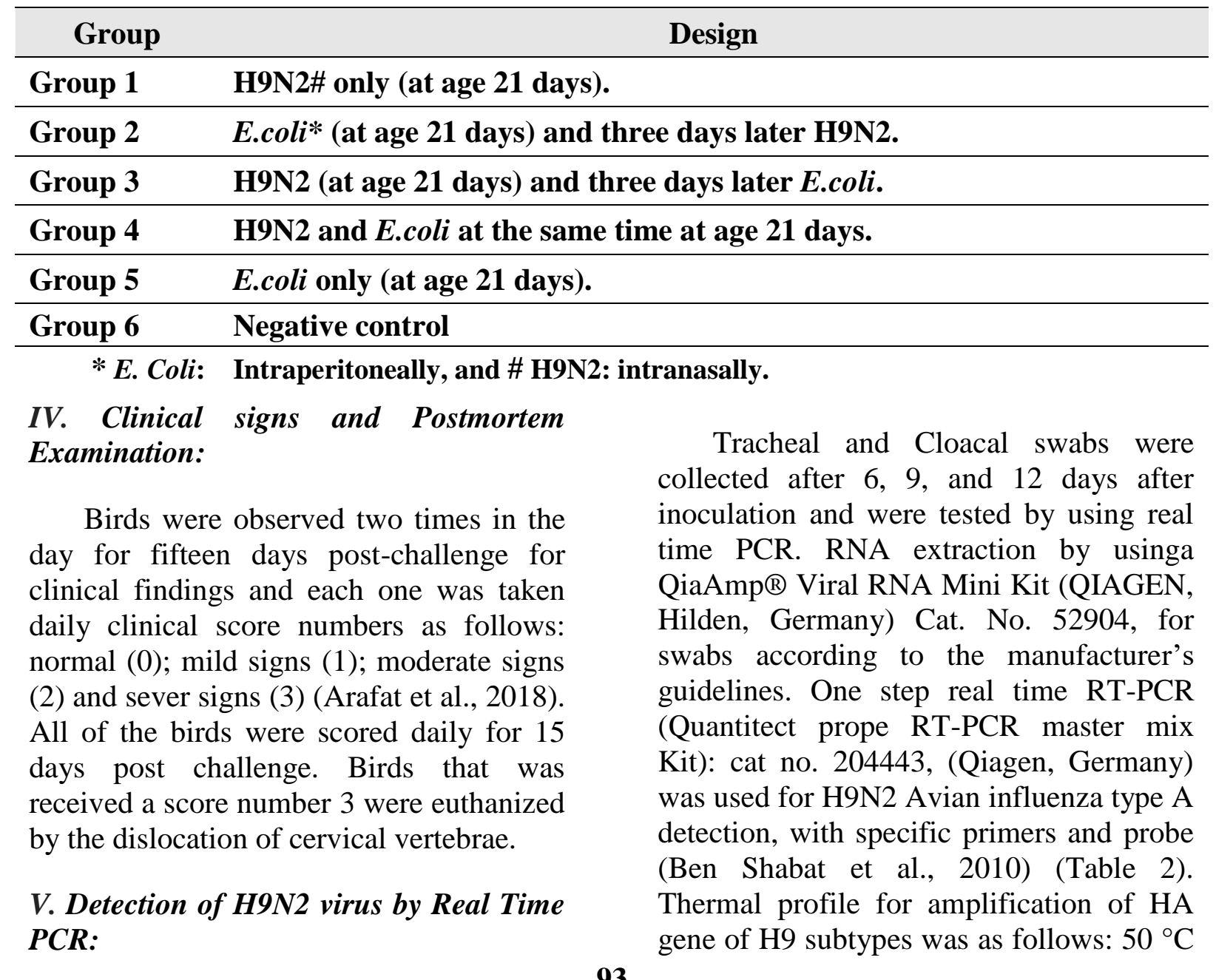


for $30 \mathrm{~min}, 95^{\circ} \mathrm{C}$ for $15 \mathrm{~min}$, cycling steps of $94^{\circ} \mathrm{C}$ for $10 \mathrm{~s}, 54^{\circ} \mathrm{C}$ for $30 \mathrm{~s}$ and $72{ }^{\circ} \mathrm{C}$ for $10 \mathrm{~s}$ repeated for 40 cycles.

VI. Serological Examination for H9N2 antibodies:
SVU-IJVS, 2 (2): 91-100

The HI antibody titers analysis was carried out after 15 days Pc (post challenge) by collection of serum from each group. Serum samples were examined for H9N2 antibodies according to (OIE, 2015).

Table (2): Primers and probe used for Real tine RT-PCR identification of H9N2 virus:

\begin{tabular}{lll}
\hline Primer ID & Primer sequences & Ref. \\
\hline \multirow{3}{*}{ H9 subtype } & $\begin{array}{l}\text { For: GGA AGA ATT AAT TAT TAT TGG TCG GTA C } \\
\text { Rev: GCC ACC TTT TTC AGT CTG ACA TT } \\
\text { H9probe: [ FAM] AAC CAG GCC AGA CAT TGC GAG TAA } \\
\text { GAT CC [TAMRA] }\end{array}$ & $\begin{array}{l}\text { (Ben } \\
\text { Shabat et } \\
\text { al., 2010) }\end{array}$ \\
\hline
\end{tabular}

\section{Results}

\section{Clinical signs and mortality rate:}

The clinical signs of this study are summarized in Table (3). In case of mortality rates, negative control group 6 showed no mortality, also the same results in mortality rates were found in group 1 which challenged by H9N2 only. Groups 3 and 4 showed high percentages of mortalities with 20\%, however the mortality rates in groups 2 and 5 revealed $10 \%$.

\section{Gross examination}

Different gross lesions were noticed during the experiment in the different groups and brief described with score system in Table (4).

Table (3): The score of the clinical signs throughout the experiment.

\begin{tabular}{lcccccc}
\hline \multicolumn{1}{c}{ Group/Clinical signs } & Group1 & Group 2 & Group 3 & Group 4 & Group 5 & Group 6 \\
\hline Coughing and sneezing & $\mathbf{1}$ & $\mathbf{2}$ & $\mathbf{2}$ & $\mathbf{3}$ & $\mathbf{1}$ & $\mathbf{0}$ \\
\hline Head enlargement & $\mathbf{0}$ & $\mathbf{1}$ & $\mathbf{1}$ & $\mathbf{2}$ & $\mathbf{1}$ & $\mathbf{0}$ \\
\hline Depression & $\mathbf{1}$ & $\mathbf{2}$ & $\mathbf{2}$ & $\mathbf{3}$ & $\mathbf{2}$ & $\mathbf{0}$ \\
\hline Respiratory distress & $\mathbf{1}$ & $\mathbf{1}$ & $\mathbf{2}$ & $\mathbf{2}$ & $\mathbf{1}$ & $\mathbf{1}$ \\
\hline Nasal and ocular discharge & $\mathbf{1}$ & $\mathbf{1}$ & $\mathbf{1}$ & $\mathbf{2}$ & $\mathbf{1}$ & $\mathbf{0}$ \\
\hline Ruffled feather & $\mathbf{1}$ & $\mathbf{1}$ & $\mathbf{2}$ & $\mathbf{2}$ & $\mathbf{2}$ & $\mathbf{0}$ \\
\hline Reluctant to move & $\mathbf{0}$ & $\mathbf{0}$ & $\mathbf{1}$ & $\mathbf{2}$ & $\mathbf{1}$ & $\mathbf{0}$ \\
\hline
\end{tabular}

(0) absence of apparent clinical disease signs, (1) mild, (2) moderate, and (3) severe signs, groups $(1,2,3,4,5$, and 6$)$. 
Table (4): The score of the gross lesions in all experimental groups.

\begin{tabular}{|c|c|c|c|c|c|c|}
\hline \multirow{2}{*}{ Lesions } & \multicolumn{6}{|c|}{ Group (G) } \\
\hline & G 1 & G 2 & G 3 & G 4 & G 5 & G 6 \\
\hline Air sacculitis & 1 & 3 & 3 & 3 & 2 & $\mathbf{0}$ \\
\hline Tracheal congestion & 1 & 3 & 3 & 3 & 2 & $\mathbf{0}$ \\
\hline $\begin{array}{l}\text { Catarrhal exudates in } \\
\text { trachea }\end{array}$ & 1 & 2 & 2 & 2 & 2 & $\mathbf{0}$ \\
\hline Serous exudates in trachea & $\mathbf{0}$ & 2 & 2 & 3 & $\mathbf{1}$ & $\mathbf{0}$ \\
\hline $\begin{array}{l}\text { Serous to cast formation in } \\
\text { the bifurcation of trachea }\end{array}$ & $\mathbf{0}$ & 3 & 3 & 2 & 1 & $\mathbf{0}$ \\
\hline Pericarditis & $\mathbf{0}$ & 3 & 3 & 3 & 2 & $\mathbf{0}$ \\
\hline $\begin{array}{l}\text { Perihepatitis and necrosis in } \\
\text { liver }\end{array}$ & 1 & 3 & 3 & 3 & 2 & $\mathbf{0}$ \\
\hline $\begin{array}{l}\text { Hemorrhages in the } \\
\text { intestine }\end{array}$ & $\mathbf{0}$ & 3 & 3 & 3 & $\mathbf{1}$ & $\mathbf{0}$ \\
\hline $\begin{array}{l}\text { Enlargement and necrosis of } \\
\text { spleen }\end{array}$ & 1 & 3 & 3 & 2 & 2 & $\mathbf{0}$ \\
\hline Enlargement of kidney & 1 & 3 & 3 & 3 & 1 & $\mathbf{0}$ \\
\hline Synovitis & 1 & 3 & 2 & 3 & 1 & $\mathbf{0}$ \\
\hline
\end{tabular}

(0) no lesions, (1) slight legions, (2) moderate lesions, and (3) severe lesions.

III. H9N2 Virus detection by Real time PCR:

All groups were examined during the experiment using real-time - PCR for virus detection in the cloacal and tracheal sample's swabs, the virus detection results with cycle threshold $(\mathrm{Ct})$ are explained in Table (5). Group 5 and group 6 showed negative results in the virus detection in the cloacal and tracheal swabs on 6, 9, 12 days post challenge. It implied that no cross contamination presented between groups. The virus was revealed in cloacal and tracheal samples in groups from 1 to 4 on day 6 after inoculation.

Only groups 3 , and 4 still given positive results in tracheal swabs on day 9 post challenge but given negative results in cloacal swabs, however, group 1, and 2 simultaneously (day 9) revealed negative results in both cloacal and tracheal samples. Also, the virus detection and shedding from cloaca wasn't detected in groups $1,2,3$, and 4 on day 12 post 1 st challenge.

\section{Serological examination}

In this study the HI titers geometric mean in groups $1,2,3$, and 4 was done on day 20 prior to challenge revealed low titers in all groups with geometric mean ranged from (2.1 to 2.3). On day 15 post challenge (the age of birds was 36 days), antibody titers against H9N2 revealed high titers in all four groups (1,2,3, and 4) however the groups 5, and 6 showed the lowest as explained in Table (6). 
Table (5): H9N2 virus detection in tracheal and cloacal swabs by RT-PCR.

\begin{tabular}{|c|c|c|c|c|c|c|}
\hline \multirow{3}{*}{ Groups } & \multicolumn{6}{|c|}{ Days post 1st challenge } \\
\hline & \multicolumn{2}{|c|}{6 days } & \multicolumn{2}{|c|}{9 days } & \multicolumn{2}{|c|}{12 days } \\
\hline & T.S. & C. S. & T.S. & C. S. & T.S. & C.S. \\
\hline Gr & $\begin{array}{c}\text { +ve } \\
(\mathrm{Ct}: 24.61)\end{array}$ & $\begin{array}{c}\text { +ve } \\
(\mathrm{Ct}: 30.17)\end{array}$ & $\begin{array}{c}-v e \\
(\text { No Ct })\end{array}$ & $\begin{array}{c}-v e \\
(\text { No Ct })\end{array}$ & $\begin{array}{c}-v e \\
(\text { No Ct })\end{array}$ & $\begin{array}{c}\text {-ve } \\
(\text { No Ct })\end{array}$ \\
\hline Gro & $\begin{array}{c}+v e \\
(\mathrm{Ct}: 25.73) \\
\end{array}$ & $\begin{array}{c}\text { +ve } \\
(\mathrm{Ct}: 34.61) \\
\end{array}$ & $\begin{array}{c}\text {-ve } \\
(\text { No Ct })\end{array}$ & $\begin{array}{c}\text {-ve } \\
(\text { No Ct })\end{array}$ & $\begin{array}{c}-v e \\
(\text { No Ct })\end{array}$ & $\begin{array}{c}\text {-ve } \\
(\text { No Ct }) \\
\end{array}$ \\
\hline Group 3 & $\begin{array}{c}+v e \\
(\mathrm{Ct}: 25.53)\end{array}$ & $\begin{array}{c}\text { +ve } \\
(\mathrm{Ct}: 31.44)\end{array}$ & $\begin{array}{c}+ \text { ve } \\
(\mathrm{Ct}: 34.17)\end{array}$ & $\begin{array}{c}\text {-ve } \\
(\text { No Ct) }\end{array}$ & $\begin{array}{c}\text {-ve } \\
(\text { No Ct) }\end{array}$ & $\begin{array}{c}\text {-ve } \\
(\text { No Ct })\end{array}$ \\
\hline Grot & $\begin{array}{c}\text { +ve } \\
\text { (Ct: } 27.27)\end{array}$ & $\begin{array}{c}\text { +ve } \\
(\mathrm{Ct}: \mathbf{3 0 . 5 1})\end{array}$ & $\begin{array}{c}\text { +ve } \\
(\mathrm{Ct}: 28.08)\end{array}$ & $\begin{array}{c}\text {-ve } \\
(\text { No Ct) }\end{array}$ & $\begin{array}{c}-v e \\
(\text { No Ct })\end{array}$ & $\begin{array}{c}\text {-ve } \\
(\text { No Ct })\end{array}$ \\
\hline Group 5 & $\begin{array}{c}-v e \\
(\text { No Ct })\end{array}$ & $\begin{array}{c}- \text { ve } \\
(\text { No Ct })\end{array}$ & $\begin{array}{c}-v e \\
(\text { No Ct })\end{array}$ & $\begin{array}{c}\text {-ve } \\
(\text { No Ct })\end{array}$ & $\begin{array}{c}\text {-ve } \\
(\text { No Ct })\end{array}$ & $\begin{array}{c}\text {-ve } \\
(\text { No Ct })\end{array}$ \\
\hline Gro & $\begin{array}{c}- \text { ve } \\
(\text { No Ct })\end{array}$ & $\begin{array}{c}-v e \\
(\text { No Ct })\end{array}$ & $\begin{array}{c}- \text { ve } \\
(\text { No Ct })\end{array}$ & $\begin{array}{c}-v e \\
(\text { No Ct })\end{array}$ & $\begin{array}{c}\text {-ve } \\
(\text { No Ct })\end{array}$ & $\begin{array}{c}\text {-ve } \\
(\text { No Ct })\end{array}$ \\
\hline
\end{tabular}

T. S.: Tracheal swabs; C. S.: Cloacal swabs; +ve: Positive; -ve: Negative, Ct: cycle threshold.

Table (6): The serological findings of $\mathrm{HI}$ titers of $\mathrm{H} 9$ antibodies of all experimental groups.

\begin{tabular}{ccccccc} 
Day & G 1 & G 2 & G 3 & G 4 & G 5 & G 6 \\
\hline $\begin{array}{c}\text { Day 20 prior challenge } \\
\text { (GMT* with SD\#) }\end{array}$ & $2.1 \pm 0.1$ & $2.2 \pm 0.1$ & $2.3 \pm 0.1$ & $2.1 \pm 0.1$ & $2.3 \pm 0.1$ & $2.2 \pm 0.1$ \\
\hline $\begin{array}{c}\text { Day 36 post challenge } \\
\text { (end of the experiment } \\
\text { (GMT with SD) }\end{array}$ & $6.5 \pm 0.2$ & $6.3 \pm 0.2$ & $7.1 \pm 0.1$ & $7.3 \pm 0.1$ & $1.0 \pm 0.0$ & $1.0 \pm 0.0$ \\
\hline
\end{tabular}

*GMT: geometric mean titer

\#SD: standard deviation.

\section{Discussion}

H9N2 virus is one of the respiratory viral diseases. It causes economic losses in broiler farms, as it is considered the primary gate for secondary bacterial infection, so the complication of mixed infection with pathogenic bacteria is very common. The natural co-infection problems usually occur simultaneously between LPAIV H9N2 and bacterial infection in poultry farms (Pan et al., 2012, $\mathrm{Pu}$ et al., 2012). Co-infection in poultry farms leads to misdiagnosis and complication in the determination of the accurate clinical picture of the problem (Pan et al., 2012, Costa-Hurtado et al., 2014). Considering the high spread of the H9N2 in chicken farms and presence of pathogenic bacteria in the same farms, this study was implemented to assess and determine the effect of bacterial coinfection especially E. coli $\mathrm{O}_{78}$ on $\mathrm{H} 9 \mathrm{~N} 2$ pathogenicity.

In this research, the clinical signs of all 6 groups were studied. Group 6 showed no observed symptoms and lesions which means that the cross infection between groups didn't occur. In the present study, 
group 5 was observed with similar findings of E.coli infection with $10 \%$ in mortality rate and observed lesions which specifically for E.coli disease, as mentioned before by (Peighambari et al., 2000). The severity of the symptoms and gross lesions increased in group 4 with higher respiratory distress and mortality rate with $20 \%$, these results match with (Ginns et al., 1998). The results in group 3 revealed the same severity of the clinical symptoms, gross examination, and mortality rate of group 4, however, the infection of the E.coli 3 days post the H9N2 inoculation, as previously reported (Barbour et al., 2009 ; Mahana et al.,2019). Converting to the group 2, there were decrease in mortality rate in comparison to group 3, and group 4 which also were coinfected with E.coli with mortality rates in both of them, however the clinical findings of the symptoms and post mortem lesions of group 2 very close to group 3, and group 4. This means, the exposure of bacterial infection (before, after, or simultaneously) with the H9N2 LPAIV increases the severity of the clinical findings and mortality rates, these signs are consistent with previous studies (Goudarzi et al., 2014; Stipkovits et al., 2012).

In case of virus shedding, groups 3 , and 4 showed prolonged duration in tracheal swabs by real time PCR than other groups, it means that the infection of the E.coli with H9N2 prolonged the persistence of H9N2 virus in trachea and upper respiratory tract which extended to 9 days post the 1st inoculation,. However, groups 1, and group 2 showed positive results in tracheal detection only after six days post the 1 st inoculation and negative results on days 9, and 12 posts the 1 st challenge. Groups 5, and group 6 implies negative results in all days post the inoculation. In the virus shedding in cloaca, the results were negative in groups
5 , and 6 in all cloacal examined swabs during the experiment, but groups $1,2,3$, and 4 were given positive results only after six days post inoculation. However the study reported by (Bano et al., 2003) revealed that the groups which were infected with H9N2 LPAIV before E.coli showed prolonged duration in the shedding of the virus until 14 days post-inoculation, in compared to groups which were infected only by H9N2 that the shedding extended up to a week after challenge.

The highest antibody titer was noticed in group 4, however, (Mosleh et al., 2017) demonstrated that receiving simultaneous H9N2 and E.coli infections showed lower antibody titer. Also, group 3 show high geometric mean number, which implies that the infection of the Ecoli with H9N2 at the same duration or after H9N2 inoculation gave high $\mathrm{HI}$ titers which was also observed by previous works (Bano et al., 2003; Mahana et al.,2019). In group 1 which inoculated H9N2 only revealed lower titer than group3 and 4, these results match with (Mosleh et al., 2017). The lowest antibody titer between groups who challenged with H9N2 appeared in group 2, these group was infected by E.coli first then after 3 days H9N2 inoculation, but other studies reported by (Mosleh et al., 2017) showed that the highest occurrence of HI antibody titer occurred when inoculating LPAI H9N2 after E.coli infection.

\section{Conclusion}

It was shown that $\mathrm{H} 9 \mathrm{~N} 2$ virus is still low in pathogenicity if it comes individually without other respiratory pathogens, however, it appears more serious if co-infected with other bacterial infection especially E.coli. In this study, the results revealed that the correlation between H9N2 and E.coli in chicken farms 
induces severe respiratory signs and high mortality rates in the suspected broiler flocks. Continuous monitoring and diagnosis of H9N2 are very important with good plans and strategies in experimental programs to identify the status of the virus and follow its development, especially in the case of co-infection with E.coli.

\section{Acknowledgement}

The authors would like to thank Dr. Heba Hassan, a researcher on Animal Health Research Institute- Reference Laboratory for Veterinary Quality Control on Poultry production (RLQP), Animal Health Research Institute, Agriculture Research Center - Dokki- Giza - Egypt) for her great help, advising, and support during this study.

\section{Conflict of interest statement}

The authors declare that they have no conflict of interest.

\section{References}

Ahmed ZA, Hussein HA, Rohaim MA (2013). Efficacy of Composting Poultry Mortality and Farms Wastes with Mixed Respiratory Infection Viruses H9N2 and NDV in Egypt. Global Veterinaria, 11(2): 177-185.

Arafat N, Eladl AH, Marghani BH, Saif MA, El-Shafei RA (2018), Enhanced infection of avian influenza virus H9N2 with infectious laryngeotracheitis vaccinationin chickens, Veterinary Microbiology, 219: 8-16.

Bano S, Naeem K, Malik SA (2003). Evaluation of pathogenic potential of avian influenza virus serotype H9N2 in chickens. Avian Diseases, 47: 817-822.
Barbour EK, Mastori FA, Abdel Nour AM, Shaib HA, Jaber LS, Yaghi RH, Sabra A, Sleiman FT, Sawaya RK, Niedzwieck A, Tayeb IT, Kassaify ZG, Rath M, Harakeh S, Barbour KE (2009). Standardization of a new model of H9N2/E.coli challenge in broilers in the Lebanon. Veterinaria Italiana, 45: 317-322.

Ben Shabat M, Meir R, Haddas R, Lapin E, Shkoda I, Raibstein I, Perk S, Davidson I, (2010). Development of a real-time TaqMan RT-PCR assay for the detection of H9N2 avian influenza viruses. Journal of Virology Methods, 168: 72-77.

Costa-Hurtado M, Afonso CL, Miller PJ, Spackman E, Kapczynski DR, Swayne DE, Shepherd E, Smith D, Zsak A, Pantin-Jackwood M (2014). Virus interference between H7N2 low pathogenic avian influenza virus and lentogenic Newcastle disease virus in experimental co-infections in chickens and turkeys. Veterinary Research, 45: 1-11.

El-Zoghby EF, Arafa AS, Hassan MK, Aly MM, Selim A, Kilany WH, Selim U, Nasef S, Aggor MG, Abdelwhab EM, Hafez HM (2012). Isolation of H9N2 avian influenza virus from bobwhite quail (Colinus virginianus) in Egypt. Archive of Virology, 157: 1167-1172.

Fernandez A, Lara C, Loste A, Marca MC (2002). Efficacy of calcium fosfomycin for the treatment of experimental infection of broiler chickens with Escherichia coli O78:K80. Veterinary Research Communication, 26: 427-436. 
Ginns CA, Browning GF, Benham ML, Whithear KG (1998). Development and application of an aerosol challenge method for reproduction of avian colibacillosis. Avian Pathology, 27: 505-511.

Goudarzi H, Azizpour A, Banani M, Nouri A, Charkhkar S, Momayez R, Hablolvarid $\mathrm{MH}$, Bijanzad $\mathrm{P}$, Mirzaei GHR, Eshratabadi F, Mahmoodzadeh M (2014). Study on clinical signs and gross lesions due to individually and concurrent experimental infection of $\mathrm{H} 9 \mathrm{~N} 2$ avian influenza and Ornithobacterium rhinotracheale in SPF chickens. Journal of Comparative Pathology, 10: 10771086.

Hassan KE, Ali A, Shany SAS, El-Kady MF (2017). Experimental coinfection of infectious bronchitis and low pathogenic avian influenza H9N2 viruses in commercial broiler chickens. Research in veterinary science $115356-$ 362.10.1016/j.rvsc.2017.06.024

Ismail ZM, El-Deeb AH, El-Safty MM, Hussein HA (2018). Enhanced pathogenicity of low-pathogenic H9N2 avian influenza virus after vaccination with infectious bronchitis live attenuated vaccine. Veterinary world 11(7) :977985.10.14202/vetworld.2018.977985

Karimi-Madab M, Ansari-Lari M, Asasi K, Nili H (2010). Risk factors for detection of bronchial casts, most frequently seen in endemic H9N2 avian influenza infection, in poultry flocks in Iran. Preventive Veterinary Medicine; 95: 275-280.

Lutful Kabir, S.M., (2010). Avian colibacillosis and salmonellosis: A closer look at epidemiology, pathogenesis, diagnosis, control and public health concerns. International Journal of Environmental Research and Public Health, 7(1), pp. 89-114.

Mahana O, Arafa AS, Erfan A, Hussein HA, Shalaby MA (2019). Pathological changes, shedding pattern and cytokines responses in chicks infected with avian influenza-H9N2 and/or infectious bronchitis viruses. Virus disease 30(2):279-287.10.1007/s13337018-00506-1

Mosleh N, Dadras H, Asasi K, Taebipour MJ, Tohidifar SS, Farjanikish Gh (2017). Evaluation of the timing of the Escherichia coli co-infection on pathogenecity of $\mathrm{H} 9 \mathrm{~N} 2$ avian influenza virus in broiler chickens, IJVR, Vol. 18, No. 2, Ser. No. 59, Pages 86-91.

OIE., 2015. Avian influenza (infection with avian influenza viruses) (OIE, OIE).

Peighambari SM, Julian RJ, Gyles CJ (2000). Experimental Escherichia coli respiratory infection in broilers. Avian Diseases, 44: 759$769 . \quad$ https://doi. org/10.2307/1593047

Persoons D, Callens B, Dewulf J, Haesebroucf F (2011). Een update van colibacillose bij kippen., pp. 161.

Pan Q, Liu A, Zhang F, Ling Y, Ou C, Hou N, He C (2012). Co-infection of broilers with Ornithobacterium rhinotracheale and $\mathrm{H} 9 \mathrm{~N} 2$ avian influenza virus. BMC Veterinary Research, 8: 104-110.

$\mathrm{Pu}$ J, Yu LF, Zhe W, Bo M, Earl GB, Jin HL (2012). Pathogenicity of H3N8 influenza viruses isolated from domestic ducks in chickens with or without Escherichia coli coinfection. Avian Diseases, 597600. 
Reed, LJ., and Muench, H (1938). A simple method of estimation of $50 \%$ end points. American Journal of Hygiene, 27:493-497.

Saif YM, Fadly AM, Glisson JR, Mcdougald LR, Nolan LK, Swayne DE, eds (2008). Diseases of Poultry. 12th edition edn. Blackwell Publishing.

Seifi S, Asasi K, Mohammadi A (2010). Natural co-infection caused by avian influenza H9 subtype and infectious bronchitis viruses in broiler chicken farms. Veterinarski Arhiv; 80: 269 - 281.

Stipkovits L, Glavits R, Palfi V, Beres A, Egyed L, Denes B, Somogyi M, Szathmary S (2012). Pathologic lesions caused by coinfection of Mycoplasma gallisepticum and
H3N8 low pathogenic avian influenza virus in chickens. Veterinary Pathology, 49: 273-283.

Suarez, DL., (2008). Influenza A virus. In: Avian Influenza. edited by Swayne D.E., -Blackwell Publishing, Ames, pp. 3-22.

Swayne DE, and Halvorson DA (2008). Influenza. In: Diseases of Poultry. Edited by Saif Y.M., Glisson J.R., McDougald L.R., Nolan L.K., Swayne D.E., Blackwell Publishing, Ames, pp. 153-184.

Tong S, Zhu X, Li Y, Shi M, Zhang J (2013). New world bats harbor diverse influenza A viruses. PLoS Pathogenicity; 9(10): e1003657. doi: 10.1371/journal.ppat.1003657. 